\title{
Food quality attributes of melon (Cucumis melo L.) influenced by grafting
}

\section{DZSENIFER NÉMETH ${ }^{1 *}$ @, GÁBOR BALÁZS ${ }^{1}$, ZSANETT BODOR $^{2}$, JOHN-LEWIS ZINIA ZAUKUU ${ }^{2}$, ZOLTÁN KOVÁCS ${ }^{2}$ and NOÉMI KAPPEL ${ }^{1}$ (i)}

\footnotetext{
${ }^{1}$ Department of Vegetable and Mushroom Growing, Szent István University, Ménesi str. 44, H-1118, Budapest, Hungary

${ }^{2}$ Department of Physics and Control, Faculty of Food Science, Szent István University, Somlói str. 14-16, H-1118, Budapest, Hungary
}

\section{CONFERENCE FULL PAPER}

Received: January 31, $2020 \bullet$ Accepted: September 24, 2020

Published online: November 2, 2020

(C) 2020 The Author(s)

\section{ABSTRACT}

Melon (Cucumis melo L.) is an important and valuable vegetable crop that nowadays has a 550ha cultivation area in Hungary. The use of grafting for cucurbits is a growing technique of interest to the food industry. Nevertheless, for melons the practice of grafting is not widespread, in contrast grafted seedlings are widely used by the watermelon growers. On the other hand, it should be mentioned that the food quality attributes can change, due to the grafting. Globally there are not many scientific articles available in this topic. The goal of our study is to provide a systematic review of literature with emphasis on the influence of grafting on melon fruit quality variations and the major advantages of this technique. Over the last few years, the near infrared spectroscopy (NIRS) and electronic tongue method became popular to measure food attributes.

\section{KEYWORDS}

grafting, melon, food quality, NIRS

\footnotetext{
*Corresponding author. E-mail: nemeth.dzsenifer@kertk.szie.hu
} 


\section{INTRODUCTION}

Grafting is a vegetative propagation method of woody plants known for 3,500 years ago. Its definition was formulated as follows: "Grafting is the art of joining together two plant parts (a rootstock and a scion) by means of tissue regeneration, in which the resulting combination of plant parts achieves physical reunion and growth as a single plant" (Janick, 1986). The success of grafting depends not only on the appropriate rootstock-scion combination, but also on how the morphological and physiological changes manifest under the given environmental and cultivation conditions (Andrews and Marquez, 1993). Grafting of vegetables was first introduced in the late 1920s in Japan and Korea, the method was used to aid the watermelon against soilborne pathogens, and to avoid various diseases caused by Fusarium species (Oda, 2002). The grafting of vegetables belonging to the family of cucurbits is not only important in terms of pest control, but also boosts the yield of the plant, its quality, the inner content values and the shelf-life of the fruit (Sakata et al., 2006, 2007, 2008).

The scion-rootstock combination can influence the quality parameters of the fruits depending on the compatibility between them, grafting often reduces the inner content values, but the fruit size is often unchanged (Lee and Oda, 2003). Studies have shown that grafting does not significantly affect physical parameters such as fruit length, width, epicarp, and flesh thickness.

Several research groups agreed that the physical characteristics of the Solanaceae and Cucurbitaceae families are not affected by grafting (Rouphael et al., 2010). However, several studies contradict the previous statements (Table 1).

According to Tarchoum et al. (2005), the growing vigor of grafted plants is stronger and higher, yields can be achieved by grafting. The quality and average weight of fruits can also be improved by grafting (Oda, 2002; Lee and Oda, 2003). The improvement of the flesh firmness, thus the improvement of shelf life, can also be attributed to the effects of grafting (Yetisir and Sari, 2003). According to Balázs (2008) and Ulas et al., (2019), grafting can have value increasing and decreasing effects as well depending on the rootstock and scion combination. In order to achieve the appropriate quality, the rootstock/scion combination should be adapted to the area of production in any case. It is important to note that many negative grafting experiences are due to the fact that growers do not adapt the water and nutrient supply to the needs of the grafted plants (Balázs, 2008).

To clarify the many grafting-related contradictions in literature, our goal is to provide a systematic review of literature with emphasis on the influence of grafting on melon fruit quality, the major advantages of this technique, and advanced analytical methods used in assessment (e-tongue and near infrared spectroscopy (NIRS)).

\section{RIPENING AND POSTHARVEST BEHAVIOR}

It has been observed that melons with climacteric respiration tend to have a shorter shelf-life, but their aromatic compound content is increased. Prolonged storage and inappropriate storage temperature may result in shorter shelf life (Cavaiuolo et al., 2015). The reason behind these changes might be that the production of some aroma compounds is limited to the ethylene dependent pathways. Melons with climacteric respiration usually have orange flesh, and high aromatic content. Typically, they have a short shelf-life due to quick softening as a result of environmental conditions. Melons with non-climacteric respiration, have mostly green flesh, they tend to have lower aromatic compound content, but they soften slowly, so they have a longer shelf-life (Wang et al., 2011). 
Table 1. Effects of grafting on melon fruit quality concluded by previous studies

\begin{tabular}{|c|c|c|c|}
\hline Parameter & Increase & Decrease & Does not change \\
\hline Yield & $\begin{array}{l}\text { Tarchoum et al., } 2005 \\
\text { Verzara et al., } 2014 \\
\text { Condoruso et al., } 2012\end{array}$ & & \\
\hline Fruit size & $\begin{array}{c}\text { Oda, } 2002 \\
\text { Lee and Oda, } 2003 \\
\text { Verzara et al., } 2014 \\
\text { Condoruso et al., } 2012\end{array}$ & & Lee and Oda, 2003 \\
\hline Fruit weight & $\begin{array}{c}\text { Colla et al., } 2010 \\
\text { Verzara et al., } 2014 \text { (C. } \\
\text { melo rootstock) } \\
\text { Colla et al., } 2006\end{array}$ & $\begin{array}{l}\text { Schulthesis et al., } \\
2015 \\
\text { Trionfetti-Nisini } \\
\text { et al., } 2002\end{array}$ & $\begin{array}{l}\text { Verzara et al., } 2014 \text { (hybrid } \\
\text { rootstock) } \\
\text { Soteriou et al., } 2016 \\
\text { Zhao et al., } 2011 \\
\text { Traka-Mavrona et al., } 2000 \\
\quad \text { Park et al., 2013 }\end{array}$ \\
\hline Fruit shape & & & $\begin{array}{c}\text { Traka-Mavrona et al., } 2000 \\
\text { Colla et al., } 2010 \\
\text { Verzara et al., } 2014 \\
\text { Soteriou et al., } 2016\end{array}$ \\
\hline $\begin{array}{l}\text { Exocarp and pulp } \\
\text { thickness }\end{array}$ & & & $\begin{array}{c}\text { Traka-Mavrona et al., } 2000 \\
\text { Colla et al., } 2010 \\
\text { Verzara et al., } 2014\end{array}$ \\
\hline $\begin{array}{l}\text { Soluble solid } \\
\text { content }\end{array}$ & $\begin{array}{l}\text { Soteriou et al., } 2016 \text { (hybrid } \\
\text { rootstock) }\end{array}$ & $\begin{array}{c}\text { Kamiya and } \\
\text { Tamura, } 1964 \\
\text { Miguel, } 1997 \\
\text { Xu et al., } 2006 \\
\text { Colla et al., } 2006 \\
\text { Colla et al., } 2010 \\
\text { Soteriou et al., } 2016 \\
\text { Schulthesis et al., } \\
2015 \\
\text { Traka-Mavrona } \\
\text { et al., 2000 } \\
\text { Park et al., } 2013\end{array}$ & $\begin{array}{l}\text { Trionfetti-Nisini et al., } \\
\qquad 2002 \\
\text { Verzara et al., } 2014 \\
\text { Soteriou et al., } 2016\end{array}$ \\
\hline $\begin{array}{l}\text { Aromatic } \\
\text { compound }\end{array}$ & $\begin{array}{l}\text { Condoruso et al., } 2012 \\
\text { Verzara et al., } 2014\end{array}$ & & \\
\hline Firmness & $\begin{array}{l}\text { Yetisir and Sari, } 2003 \\
\text { Colla et al., } 2006 \\
\text { Colla et al., } 2010\end{array}$ & $\begin{array}{l}\text { Soteriou et al., } 2016 \\
\text { Zhao et al., } 2011\end{array}$ & $\begin{array}{l}\text { Crino et al., } 2007 \\
\text { Guan et al., } 2015 \\
\text { Fita et al., } 2007\end{array}$ \\
\hline Vitrescence & $\begin{array}{c}\text { Jang et al., 2014, Rouphael } \\
\text { et al., 2010, Colla et al., } \\
2017\end{array}$ & & \\
\hline
\end{tabular}


Table 1. Continued

\begin{tabular}{lccc}
\hline Parameter & Increase & Decrease & Does not change \\
\hline $\begin{array}{l}\text { Organo-leptic } \\
\text { assessment }\end{array}$ & Rouphael et al., & \\
Shelf life & Lee, 2003 & & \\
$\begin{array}{l}\text { Dry matter content } \\
\text { Fruit quality }\end{array}$ & Davis et al., 2008 & Colla et al., 2010 & Crino et al., 2007 \\
\hline
\end{tabular}

Researches showed that grafting may decrease flesh firmness of the fruit, which results in a shorter storage life. This may however, not be the case in every rootstock. Grafting on the right rootstock may result in nearly identical flesh firmness, as in melons grown on their own root or grafted on themselves (Zhao et al., 2011). According to Lester and Saftner (2008), shelf life is reduced by washing, loading, packaging, and "ready to eat" preparation.

\section{PHYSIOLOGICAL DISORDERS}

The development of vitrescence in melons is often used to refer to the effect of grafting (Jang et al., 2014; Rouphael et al., 2010; Colla et al., 2017). Softening and vitrescence can usually be observed due to forcing in autumn and in cultivation in summer when a variety with traits of lower flesh firmness is grafted to "Shintosa" rootstock. Jang et al. (2014), revealed that plants grafted to "Shintosa" rootstock developed vitrescence in $89 \%$ of the plansts, in contrast only $50 \%$ of plants grown on their own roots showed this problem. Plants grafted on melon rootstock showed an even lower vitrescence development rate. Low calcium content may contribute to softening and the development of vitrescence too (Johnstone et al., 2008). Lower phosphorus, calcium and magnesium content can be detected in case of plants grafted to "Shintosa" rootstock, than in plants grown on their own roots, or plants grafted to melon rootstock.

\section{SOLUBLE SOLID CONTENT}

Total soluble sugar can be determined in $\mathrm{Brix}^{\circ}$, which enables to predict fruit quality. Measurements of Brix can be carried out with a refractometer (Burger et al., 2006). The acceptable minimum soluble sugar content of melon is 9 Brix $^{\circ}$ (Bianco and Pratt, 1977), but Munshi and Alverz (2004) defined the minimum soluble sugar of melon by $10 \%$. It is important to harvest melons at the appropriate ripening stage (Burger et al., 2006), since in the last stage (10 days before harvest) in parallel with the drastic decline of invers acid enzyme levels the sucrose content increases significantly (Lingle and Dunlap, 1987; Stepansky et al., 1999).

The research of Kamiya and Tamura (1964) reveals that if "Earl's Favorite" melon scions are grafted on Cucurbita spp. rootstock, the fruits grow faster than on self-rooted plants, but the fruit netting becomes poorer and sugar content is only 2-3 Brix ${ }^{\circ}$. In the late 1940s Imazu (1949) reported that the Cucurbita moschata rootstock caused a weaker texture and aroma in the grafted Honey Dew' fruits, but increased tolerance against fusarium wilt. Grafting did reduce 
sugar content by $1 \mathrm{Brix}^{\circ}$ in case of watermelon and melon as well (Miguel, 1997; Xu et al., 2006). In addition to grafting, different storage conditions can also have some influence on the soluble solid and organic acid content of the fruits (Guerreiro et al., 2017).

\section{AROMA VOLATILES}

Grafting and the rootstock selection also influence the taste and aroma compounds (Davis et al., 2008; Rouphael et al., 2010).

The taste of different fruits and vegetables is unique (Bett, 2002). Aroma and taste are generally among the most important organoleptic properties in fruits and vegetables, a variety of volatile compounds, as well as sugars and the acidity, contribute to their intensity in the crops (Verzera et al., 2014).

There are several compounds with different volatility in melon fruits, such as esters, alcohols, and carbonyl compounds, especially those containing a straight chain of nine carbon atoms. Aroma is strongly dependent on the fruit variety and the physiological processes of the plants and also shows some correlation with the matrix effect of changes (Dos-Santos et al., 2013; Harker and Johnston, 2011).

The most important aromatic compounds include amino acid compounds, lipid derived compounds, phenol derivatives and mono- and sesquiterpenes (Schwab et al., 2008). Verzera et al. (2014) reported that the proportion of the most important aromatic esters, such as ethyl 2-methylbutanoate and ethyl butanoate (could be 20-95\% less than in the control) when "Proteo" melon scions were grafted on "Polifemo", "AS10", "RS841", "P360" and "Energy" rootstocks. Octyl acetate and isobutyl acetate decreased when "Galia C8" was grafted to "RS841" rootstocks, while the content of 2-methylbutyl acetate was similar to the nongrafted melons, however the proportion of ethylhexonate was higher in grafted plants. The latter compounds positively influenced the succulent and sweet taste (Yarsi et al., 2012).

Changes in climatic conditions, storage temperature, and level of ripeness are parameters that can displace accustomed flavors to unfamiliar ones. In addition, it has been observed that the taste of pumpkins and cucumbers can be observed in unripe melons, but is not perceptible in ripe melon fruits (Bett, 2002).

Grafting does change the taste and the aromatic compound content of the fruits, in case of "Honey Dew" melon, a more robust fruity taste and aroma can be perceived. The compounds responsible for the taste of melon are amino acid-derived compounds, lipid-derived compounds, phenol-derived compounds, mono-, and sesquiterpenes (Schwab et al., 2008). The isolation of these compounds can be achieved with solid phase microextraction technique (SPME). For identification and quantification of these compounds gas chromatography coupled on line with mass spectrometry (GC-MS) is used.

Certain plants have specific aroma components that are genetically encoded and defined (Korány et al., 2000). These components are determined by advanced analytical methods that use the aromatic composition of the fruit to verify origin (variety) and quality (Kocsis et al., 2003; Majoros et al., 2006).

The simplest and most commonly used method for the measurement of volatile aroma components is gas chromatography separation coupled to a mass spectrometric detector (Szamosi, 2009).

However, in GC-MS analysis, it is important that the sample is properly prepared, and that the extraction method for the volatile aroma compounds is correctly selected as this will largely determine the success and accuracy of the assay. Melon aroma evaluation is usually carried out from the fruit flesh after removing the peel and kernels (Horvát and Stener, 1987). 
In addition, recent research has shown that volatile aroma components are present in higher levels in the melon peel than in the flesh (Aubert and Pitrat, 2006).

\section{NEAR INFRARED SPECTROSCOPY}

Food science and food industry preferentially use analytical instruments which enable fast and cost-effective examinations. NIRS is a method which provides qualitative and quantitative analysis of food and operates on the basics of the analyte interacting with electromagnetic radiation between 780 and 2,500 $\mathrm{nm}$ (Fig. 1). Among others, antioxidant capacity, sugar, carotine, vitamin $\mathrm{C}$, caffeine, and water content of different food products can be measured with NIRS (Huck et al., 2005; Szegedi et al., 2011; Magzawa et al., 2013). NIRS requires a small sample size and is non-invasive and is relatively fast (Rácz, 2016).

Lu et al. (2015) measured Soluble Solids Content (SSC) and firmness using visible-nearinfrared (VIS-NIR) spectroscopy in four different melon varieties. The reference values were determined with traditional methods, SSC was measured on a digital refractometer and firmness was measured with a hand-held penetrometer. The K-BA100R type spectrophotometer was found to be the most suitable using the VIS-NIR spectral range (500-1,010 nm, 2 $\mathrm{nm}$ spectral interval) Four different algorithms (uninformative variables elimination (UVE), uninformative variables elimination-successive projections algorithm (UVE-SPA), genetic algorithm (GA), uninformative variables elimination-genetic algorithm (UVE-GA)) were used for the Partial Least Squares (PLSs) regression models. The best results were achieved using the Genetic algorithm and partial least square (GA-PLS) model, this enabled the most wavelength combination, and the wide search range also helped the reliability of the model.

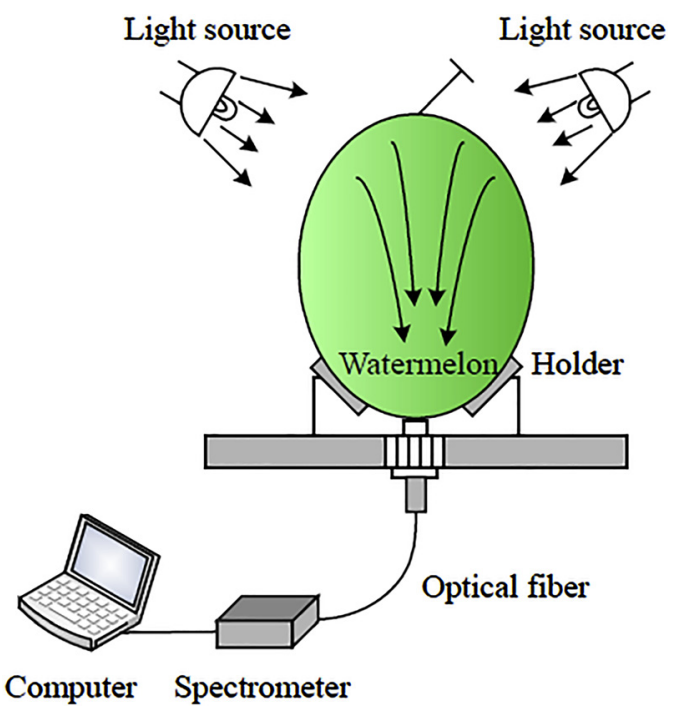

Fig. 1. Outline of a spectrum detection system Tian et al. (2007) 
Long (2005) also measured SSC content in melon using NIRS. He came to the conclusion that the calibration model was more reliable on the samples taken from the outer tissues of the mezocarpium. He also concluded that the performance of the model depended on the variety.

The measurement of more inner content values have been studied using FT-NIRS, for example antioxidant capacity, $\gamma$-aminobutyric acid content, sugar content, vitamin E and C content (Rácz, 2016, Németh et al., 2019). When used properly, NIRS can be a cost-efficient, and precise method.

\section{ELECTRONIC TONGUE}

"Electronic tongues are defined as an array of non-specific chemical sensors with partial sensitivity (cross-sensitivity) to different components, able to analyze complex liquids. The sensor array produces signals which are not necessarily specific for any particular species in the liquid, but a signal pattern is generated which can be related to certain features or qualities of the sample using the appropriate software" (Rodríguez-Méndez et al., 2010).

The electronic tongue is able to distinguish solutions from each other in a sensitive way. The threshold of the electronic tongue's sensors must be the similar as the human taste threshold and it must detect interactions between taste substances just as human receptors (Bhattacharyya and Bandhopadhyay, 2010; Kobayashi, 2005).

The sensor array creates signals that are not necessarily specific for any particular species in the liquid, but the generated signal pattern can be related to certain qualities of the sample (RodríguezMéndez et al., 2010). On Fig. 2 the structure of an electronic tongue setup can be seen.

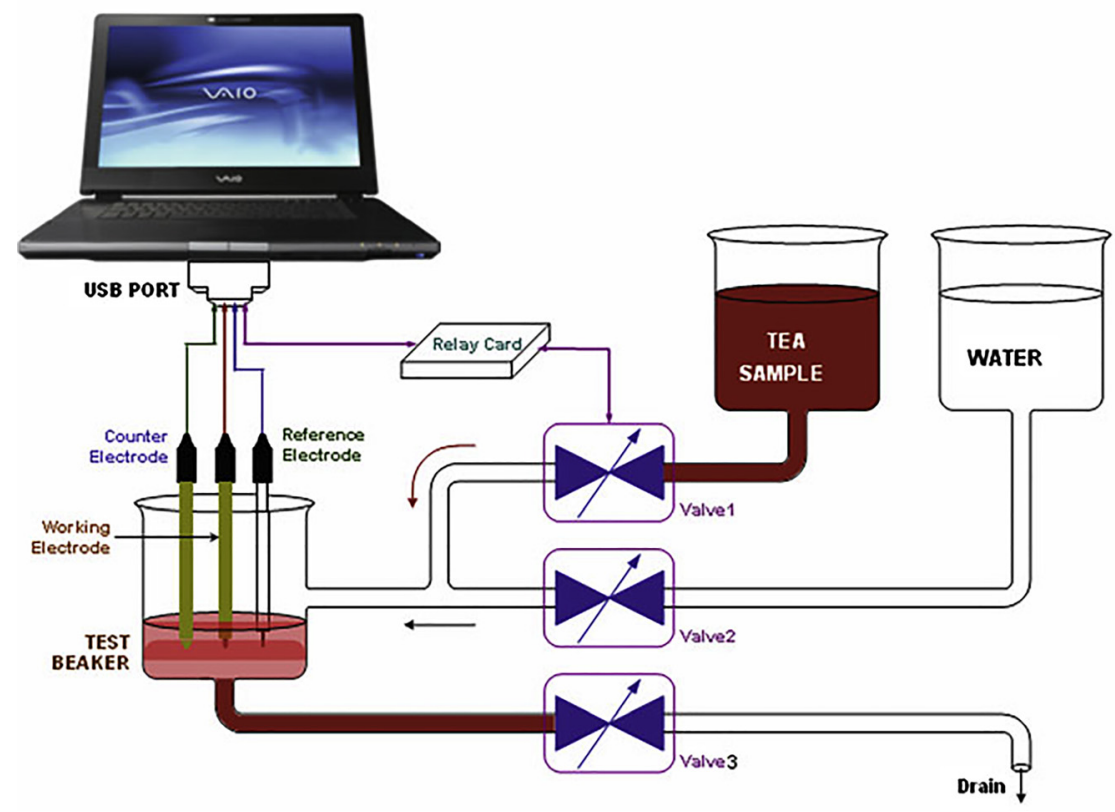

Fig. 2. Internal structure of electronic tongue, Bhattacharyya and Bandhopadhyay (2010) 
Electronic tongue has a key role in the food industry. It can be used to investigate freshness, shelf life, and originality, as well as food characterization, quantitative analysis and process tracking (Escuder-Gilabert and Peris, 2010).

Fekete et al. (2018) tried to confirm the effects of grafting on the nutritional parameters of watermelon using electronic tongue and organoleptic evaluation. In their experiments they came to the conclusion that the production area and the technology used have a more significant effect on the quality of the fruit than grafting. Top level technologies achieved the same quality as grafting, regardless of the type of the rootstock.

Kantor et al. (2008) investigated the changes in taste during storage in different apricot varieties. Refraction and $\mathrm{pH}$ measurements as well as sensory evaluations were used as reference method. The electronic tongue was able to distinguish between the different storage modes and confirmed the results measured by the reference methods.

With the use of correlative analytical methods (NIR and Electronic tongue) it is easy to distinguish between Galia and Cantaloupe type melons and between the varieties. By combining the two techniques, it is possible to monitor quickly and non-destructively the effects of grafting and storage on the organoleptic and nutritional parameters of melons (Németh et al., 2019).

\section{SENSORY EVALUATION}

Modern melon growing programs have to consider aspects of fruit quality which are often left out, such as sensory parameters examined from a consumer point of view. Sensory evaluation provides information on how consumers perceive and respond to food products in real life, this information is even more credible if it is also supported by instrumental measurements (Schiffman, 1996).

The quality of melon fruit is made up of several factors such as the visual appearance, texture, and the taste and aroma, which are the most important attributes for consumers (Escribano et al., 2010).

According to Vallone et al. (2013) physiological changes during ripening and harvesting at the appropriate ripeness are key in achieving good organoleptic parameters. Melons, when properly ripe, have a sweet, fruity taste, and aroma, whereas the unripe fruit is usually characterized by its cucumber taste and aroma. There is a significant association between melon 2-heptenal levels and "cucumber taste", according to the study.

The aroma and the right texture greatly influence the consumer satisfaction (Bett-Garber et al. 2003).

Bett-Garber et al. (2003) compared the organoleptic properties of four Cantaloupe type melon varieties and found that sweet taste and aroma, flesh firmness and water content are also variety dependent. The "Athena", "Primo", and "Sol Real" varieties are much sweeter than "Pacstart".

Ayres et al. (2019) compared the organoleptic properties of 15 Cantaloupe type melon on the basis of flavor, taste, and texture. The varieties were the most easily distinguished by their flesh color, sweetness, firmness, and juiciness. The critics preferred the medium-ripening varieties "Magellan" and "Acclaim". Significant differences were found between the organoleptic parameters of different cultivars, irrespective of whether the cultivar was early or late ripening. Overall, it was concluded that sensory parameters are not influenced by the growing cycle.

Storage affects the organoleptic properties of melon fruits. The optimum storage temperature is $4{ }^{\circ} \mathrm{C}$ for 7 days. As a result of storage, the sweet, fruity taste and the flesh firmness of the pulp 
decreases regardless of the variety (Bett-Garber et al., 2003). Bett-Garber et al., (2011) examined the effect of different storage temperatures on the organoleptic properties of melons. Melons were stored at 4 or $10{ }^{\circ} \mathrm{C}$ and after 24 or $48 \mathrm{~h}$ some of the fruits have been moved from 4 to 10 ${ }^{\circ} \mathrm{C}$. Organoleptic analysis has been conducted on the $2 \mathrm{nd}, 5 \mathrm{th}$, and 7 th day of storage. It was concluded that temperature changes during storage negatively affect the quality of the fruit, melon aroma, and taste, sweet aroma were worse, and the textural properties also changed compared to the control $\left(10{ }^{\circ} \mathrm{C}\right)$.

Miccolis et al., (1995) stored different melon varieties at 7, 12, and $15{ }^{\circ} \mathrm{C}$ for 3 weeks and after that at $20{ }^{\circ} \mathrm{C}$ for 3 days. He found that flesh firmness depends on the variety but is also influenced by the storage conditions.

Özdemir et al. (2016) compared the shelf life and storage life of self-rooted and grafted watermelons. Watermelons were stored at $7{ }^{\circ} \mathrm{C}$ for 21 days then at $21{ }^{\circ} \mathrm{C}$ for 7 days. They found that the watermelons grafted on the "Ferro" and "RS841" rootstocks had better flesh firmness, less crackings, and more intense flesh color than the self-rooted ones, also their lycopene content was higher.

The vintage effect can significantly influence the organoleptic parameters of melons (BettGarber et al., 2003).

\section{CONCLUSION}

Grafting of cucurbits is very popular today. Grafted seedlings are widely used by the watermelon growers, however, for melons the practice of grafting is not widespread. Literature and the attitude of the growers towards the subject are very different, positive as well as negative experiences are reported. Grafting may affect the ripening, yield and inner content of the fruit. The refraction, the composition of the aromatics and the formation of vitrification may also change. Most melons are climacteric fruits, so proper storage parameters can influence their quality, due to this it is advisable to investigate the effects of grafting and storage together. It is important to note that many negative grafting experiences are due to the fact that growers do not adapt the water and nutrient supply to the needs of the grafted plant. Nowadays it is possible to use newly spread correlative analytical methods (NIR, electronic tongue), that are easier, faster, and non-destructive, organoleptic evaluations and standard analytical measurement methods, to determine melon inner content values.

\section{ACKNOWLEDGEMENTS}

Supported by the by the ÚNKP-20-3 (N.Dzs., Zs.B.) and ÚNKP-20-4 (Z.K.) New National Excellence Program of the Ministry for Innovation and Technology.

This research was supported by the Higher Education Institutional Excellence Program (204303/2018/FEKUTSTRAT) awarded by the Ministry of Human Capacities within the framework of plant breeding and plant protection research at Szent István University.

This publication is created in number EFOP-3.6.1-16-2016-00016. The SZIE Campus of Szarvas specialized in research and training profiles with intelligent specialization in the themes of water management, hydroculture, precision mechanical engineering, alternative crop production". The project is supported by the European Union and co-financed by the European Social Fund (grant agreement no. EFOP-3.6.3-VEKOP-16-2017-00005). 
This research was supported by the Higher Education Institutional Excellence Program (1783-3/ 2018/FEKUTSTRAT) awarded by the Ministry of Human Capacities within the framework of water-related research at Szent István University. Program (20430-3/2018/FEKUTSTRAT) awarded by the Ministry of Human Capacities within the framework of plant breeding and plant protection research at Szent István University.

\section{REFERENCES}

Andrews, P.K. and Marquez, C.S. (1993). Grafting Incompatibility - Horticulural Reviews. American Society of Horticulural Science, 15: 183-232.

Aubert, C. and Pitrat, M. (2006). Volatile compounds in the skin and pulp of Queen Anne's pocket melon. Journal of Agricultural and Food Chemistry, 54: 8177-8182.

Ayres, E.M.M., Lee, S.M., Boyden, L., and Guinard, J-X. (2019). Sensory properties and consumer acceptance of cantaloupe melon cultivars. Journal of Food Science, 84(8): 2278-2288.

Balázs, G. (2008). Az oltás hatása a sárgadinnye terméseredményére. Kertgazdaság, 40(4): 3-7.

Bett, K. (2002). Evaluating sensory quality of fresh-cut fruits and vegetables. In: Bett, K. (Ed.), Fresh-cut fruits and vegetables. Science, technology and market. CRC Press, Boca Raton, pp. 427-438. Submitted for publication.

Bett-Garber, K.L., Beaulieu, J.C., and Ingram, D.A. (2003). Effect of storage on sensory properties of freshcut cantaloupe varieties, Journal of Food Quality, 26: 323-335.

Bett-Garber, K.L., Greene, J.L., Lamikanra, O., Ingram, D.A., and Watson, M.A. (2011). Effect of storage temperature variations on sensory quality of fresh-cut cantaloupe melon. Journal of Food Quality, 34: 19-29.

Bhattacharyya, N., Bandhopadhyay, R., 2010. Electronic nose and electronic tongue. In: Jha, S.N. (Ed.), Nondestructive Evaluation of food quality. Springer-Verlag, Berlin and Heidelberg, pp. 73-100.

Bianco, V.V. and Patt, H.K. (1977). Compositional changes in muskmelon during development and in response to ethylene treatment. Journal of the American Society for Horticultural Science, 102: 127-133.

Burger, Y., Sa'ar, U., Paris, H.S., Lewinsohn, E., Katzir, N., Tadamor, Y., and Schaffer, A.A. (2006). Genetic variability for valuable fruit quality traits in Cucumis melo. Israel Journal of Plant Sciences, 54: 233-242.

Cavaiuolo, M., Cocetta, G., Bulgari, R., Spinardi, A., and Ferrante, A. (2015). Identification of innovative potential quality markers in rocket and melon fresh-cut produce. Food Chemistry, 188: 225-233.

Colla, G., Pérez-Alfoecea, F., and Schwarz, D. (2017). Vegetable Grafting principles and practices. CABI, UK. pp. 155-170.

Colla, G., Rouphael, Y., Cardarelli, M., Massa, D., Salerno, A., and Rea, E. (2006). Yield, fruit quality and mineral composition of grafted melon plants grown under saline conditions. Journal of Horticultural Science and Biotechnology, 81: 146-152.

Colla, G., Suãrez, C. M. C., Cardarelli, M., and Rouphael, Y. (2010). Improving nitrogen use efficiency in melon by grafting. HortScience, 45: 559-565.

Condurso, C., Verzera, A., Dima, G., Tripodi, G., Crinò, P., Paratore, A., and Romano, D. (2012). Effects of different rootstocks on aroma volatile compounds and carotenoid content of melon fruits. Scientia Horticulturae, 148: 9-16.

Crinò, P., Lo Bianco, C., Rouphael, Y., Colla, G., Saccardo, F., and Paratore, A. (2007). Evaluation of rootstock resistance to Fusarium wilt and gummy stem blight and effect on yield and quality of a grafted 'Inodorus' melon. HortScience, 42: 521-525. 
Davis, A.R., Perkins-Veazie, P., Hassell, R., Levi, A., King, S.R., and Zhang, X. (2008). Grafting effects on vegetable quality. HortScience, 43: 1670-1672.

Dos-Santos, N., Bucso, M.C., and Fernández-Trujillo, J.P. (2013). Aroma volatiles as biomarkers of textural differences at harvest in non-climacteric near-isogenic lines of melon. Food Research International, 54(2): 1801-1812. https://doi.org/10.1016/j.foodres.2013.09.031.

Escribano, S., Sanchez, F.J., and Lazaro, A. (2010). Establishment of a sensory characterization protocol for melon (Cucumis melo L.) and its correlation with physical-chemical attributes: indications for future genetic improvements. European Food Research and Technology, 231: 611-621.

Escuder-Gilabert, L. and Peris, M. (2010) Review: highlights in recent applications of electronic tongues in food analysis. Analytica Chimica Acta, 665(1): 15-25.

Fekete, D., Balázs, G., Bőhm, V., Várvölgyi, E., and Kappel, N. (2018). Sensory evaluation and electronic tongue for sensing grafted and non-grafted watermelon taste attributes. Acta Alimentaria, 47(4): 487-494.

Fita, A., Pico, B., Roig, C., and Nuez, F. (2007). Performance of Cucumis melo ssp. agrestis as a rootstock for melon. Journal of Horticultural Science and Biotechnology, 82: 184-190.

Guan, W., Zhao, X., Hubler, J.H., Huber, J.D., and Sims, A.C. (2015). Instrumental and sensory analyses of quality attributes of grafted specialty melons. Journal of the Science of Food and Agriculture, 95: 2989-2995.

Guerreiro, A.C., Gago, C.M.L., Faleiro, M.L., Miguel, M.G.C., and Antunes, M.D.C. (2017). The effect of edible coatings on the nutritional quality of 'Bravo de Esmolfe' fresh-cut apple through shelf-life: food science + technology. Science + technologie alimentaire. LWT - Food Science and Technology, 75: 210-219.

Harker, F.R. and Johnston, J. (2011). Importance of texture in fruit and its interaction with flavor. Food Analytical Methods, 4: 141-149.

Horvat, R.J. and Sener, S.D. (1987). Identification of additional volatile compounds from cantaloupe. Journal of Food Science, 52(4): 1097-1098.

Huck, C.W., Guggenbichler, W., and Bonn, G.K. (2005). Analysis of caffeine, theobromine and theophylline in coffee by near infrared spectroscopy (NIRS) compared to high-performance liquid chromatography (HPLC) coupled to mass spectrometry. Analytica Chimica Acta, 538(1-2): 195-203.

Imazu, T. (1949). On the symbiotic affinity caused by grafting among Cucurbitaceous species. Journal of the Japanese Society for Horticultural Science, 18: 6-42.

Jang, Y., Huh, Y-C., Park, D-K., Mun, B., Lee, S., and Um, Y. (2014). Greenhouse evaluation of melon rootstock resistance to monosporascus root rot and vine decline as well as of yield and fruit quality in graftes 'inodorus' melons. Horticultural Science and Technology, 32(5): 614-622.

Janick, J. (1986). Horticultural science, 4th ed. W.H. Freeman \& Co., New York.

Johnstone, P.R., Hartz, T.K., and May, D.M. (2008). Calcium fertigation ineffective at increasing fruit yield and quality of muskmelon and honeydew melons in California. HortTechnology, 18: 685-689.

Kamiya, E. and Tamura, S. (1964). Studies on grafting in muskmelon (in Japanese). Bulletin of Shizuoka Agricultural Experiment Station, 9: 79-83.

Kantor, D.B., Hitka, G., Fekete, A., and Balla, CS. (2008). Electronic tongue for sensing taste changes with apricots during storage. Sensors and Actuators, 131: 43-47.

Kobayashi, K. (2005). Vegetable grafting robot. Research Journal of Food and Agriculture, 28: 15-20.

Kocsis, N., Márkus, F., Mednyánszky, Zs., Amtmann, M., and Korány, K. (2003). Recognition experiments of the vintage year 1997 hot and red paprika (Capsicum annum) varieties grown in Kalocsa. Acta Alimentaria, 32(1): 63-75.

Korány, K., Mednyánszky, Zs., and Amtmann, M. (2000). Preliminary results of a recognition method visualizing the aroma and fragrance features. Acta Alimentaria, 29(2): 187-198. 
Lee, J.M. and Oda, M. (2003). Grafting of herbaceous vegetable and ornamental crops. In: Janick, J. (Ed.), Horticultural reviews, Vol. 28, John Wiley \& Sons, New York, NY, pp. 61-124.

Lee, Y.M. (2003). Advences in vegetable grafting. Cronica Horticulturae, 43(2): 13-19.

Lester, G.E. and Saftner, R.A. (2008). Marketable quality and phytonutrient concentrations of a novel hybrid muskmelon intended for the fresh-cut industry and its parental lines: whole-fruit comparisons at harvest and following long-term storage at 1 or $5{ }^{\circ} \mathrm{C}$. Postharvest Biology and Technology, 48: 248-253.

Lingle, S.E. and Dunlap, J.R. (1987). Sucrose metabolism in netted muskmelon fruit development. Plant Physiology, 84: 386-389.

Long, R.L. (2005). Improving fruit soluble solids content in melon (Cucumis melo L.) (reticulatus group) in the Australian production system. Doctoral dissertation, Central Queensland University. 72-96, 121-135.

Lu, J., Qi, S., Liu, R., Zhou, E., Li, W., Song, S., and Han, D. (2015). Nondescructive determination of soluble solids and firmness in mix-cultivar melon using near- infrared CCD spectroscopy. Journal of Innovative Optical Health Sciences, 8(6): 1-8.

Magwaza, L.S., Opara, U.L., Terry, L. A., Landahl, S., Cronje, P.J.R., Nieuwoudt, H.H., and Hanssens, A. (2013). Evaluation of Fourier transform-NIR spectroscopy for integrated external and internal quality assessment of Valencia oranges. Journal of Food Composition and Analysis, 31(1): 144-154.

Majoros, E.L., Csóka, M., and Korány, K. (2006). Sárgabarack-gyümölcs, pálinka és -szeszesital aromatulajdonságainak feltérképezése GC-MS vizsgálatokkal. Élelmiszervizsgálati Közlemények (Élelmiszerminöség-Élelmiszerbiztonság), 7(2): 77-84.

Miccolis, V. and Saltveit, M.E. (1995). Influence of storage period and temperature on the postharvest characteristics of six melon (Cucumis melo L., Inodorus Group) cultivars. Postharvest Biology and Technology, 5(3): 211-219.

Miguel, A. (1997). Injerto de hortalizas. Serie Divulgacion Tecnica. Conselleŕa de Agricultura, Pescay Alimentaciacutéon. Generalitat Valenciana, Valencia, pp. 50-52.

Munshi, A.D. and Alverz, J.M. (2004). Hybrid melon development. In: Singh, P.K., Dasgupta, S.K., and Tripathi, S.K. (Szerk), Hybrid vegetable development, Food Products Press, pp. 289-322.

Németh, Dzs., Balazs, G., Hussein, G.D., Kovacs, Z., Bodor, Zs., Zinia, J.-L.Z, Szentpeteri, V., Kokai, Z., and Kappel, N. (2019). Standard analytical methods, sensory evaluation, NIRS and electronic tongue for sensing taste attributes of different melon varieties. Sensors, 19(5010): 1-20.

Oda, M. (2002). Grafting of vegetable crops. Scientific Report of Agriculture and Biology Sciences, Osaka Prefecture University, 54: 49-72.

Özdemir, A.E., Çandır, E., Yetişir, H., Aras, V., Arslan, Ö., Baltaer, Ö., Üstün, D., and Ünlü, M. (2016). Effects of rootstocks on storage and shelf life of grafted watermelons. Journal of Applied Botany and Food Quality, 89: 191-201.

Park, D.K., Son, S.H., Kim, S., Lee, W.M., Lee, H.J., Choi, H.S., Yang, E.Y., Chae, W.B., Ko, H.-C., and Huh, Y.-C. (2013). Selection of melon genotypes with resistance to Fusarium wilt and Monosporascus root rot for rootstocks. Plant Breeding and Biotechnology, 1: 277-282.

Rácz A. (2016). Kemometria ás FT-NIR spektroszkópia alkalmazása az élelmiszeranalitikában. PhD. értekezés, Budapest.

Rodríguez-Méndez, M.L., Apetrei, C., and De Saja, J.A. (2010). Electronic tongues purposely designed for the organoleptic characterization of olive oils.Olives and Olive Oil in Health and Disease Prevention. Chapter 59. 527-532.

Rouphael, Y., Schwarz, D., Krumbein, A., and Colla, G. (2010). Impact of grafting on product quality of fruit vegetables. Scientia Horticulturae, 127: 172-179. 
Sakata, Y., Ohara, T., and Sugiyama, M. (2007). The history and present state of the grafting of cucurbitaceous vegetables in Japan. Acta Horticulturae, 731: 159-170.

Sakata, Y., Ohara, T., and Sugiyama, M. (2008). The history of melon and cucumber grafting in Japan. Acta Horticulturae, 767: 217-228.

Sakata, Y., Sugiyama, M., Ohara, T., and Morishita, M. (2006). Influence of rootstock on the resistance of grafted cucumber (Cucumis sativus L.) scions to powdery mildew (Phodosphaera xantii U. Braun \& N. Shishkoff). Journal of Japanaese Society for Horticultural Sciences, 75: 135-140.

Schiffman H.R. (1996). Sensation and perception: an integrated approach, John Wiley \& Sons, New York.

Schultheis, J., Thompson, W., and Hassel, R. (2015). Specialty melon yield and quality response to grafting in trials conducted in the Southeastern United States. Acta Horticulturae, 1086: 269-278.

Schwab, W., Davidovich-Rikanti, R., and Lewinsohn, E. (2008). Biosynthesis of plant-derived flavor compounds. Plant Journal, 54: 712-732.

Soteriou, G.A., Papayiannis, L.C., and Kyriacou, M.C. (2016). Indexing melon physiological decline to fruit quality and vine morphometric parameters. Scientia Horticulturae, 203: 207-215.

Stepansky, A., Kovalski, I., Schaffer, A.A., and Perl-Treves, R. (1999). Variation in sugar levels and invertase activity in mature fruit representing a board spectrum of Cucumis melo genotypes. Genetic Resources and Crop Evolution, 46: 53-62.

Szamosi, Cs. (2009). Tradicionális sárga-és görögdinnyék különleges értékei. Doktori értekezés, Budapest.

Szegedi, T., Dernovics, M., and Fodor, M. (2011). Determination of protein, lipid and sugar contents of bakery products by using fourier-transform near infrared spectroscopy. Acta Alimentaria, 40: 21.

Tarchoun, N., Boughalleb, N., and El Mbakri, A. (2005). Agronomic evaluation of nine cucurbit rootstocks and watermelon grafted (Citrullus lanatus T.) Revue de l'INAT, 20: 125-140.

Tian, H., Ying, Y., Lu, H., Fu, X., and Yu, H. (2007). Measurement of soluble solids content in watermelon by Vis/NIR diffuse transmittance technique. Journal of Zhejiang University Science B, 8(2): 105-110. https://doi.org/10.1631/jzus.2007.B0105.

Traka-Mavrona, E., Koutsika-Sotiriou, M., and Pritsa, T. (2000). Response of squash (Cucurbita spp.) as rootstock for melon (Cucumis melo L.). Scientia Horticulturae, 83: 353-362.

Trionfetti-Nisini, P., Colla, G., Granati, E., Temperini, O., Crinò, P., and Saccardo, F. (2002). Rootstock resistance to Fusarium wilt and effect on fruit yield and quality of two muskmelon cultivars. Scientia Horticulturae, 93: 281-288.

Ulas, F., Aydın, A., Ulas,A., and Yetisir, H. (2019). Grafting for sustainable growth performance of melon (Cucumis melo) under salt stressed hydroponic condition. European Journal of Sustainable Development, 8(1): 201-210.

Vallone, S., Sivertsen, H., Anthon, G.E., Barrett, D.M., Mitcham, E. J., Ebeler, S.E., and Zakharov, F. (2013). An integrated approach for flavour quality evaluation in muskmelon (Cucumis melo L. reticulatus group) during ripening. Food Chemistry, 139: 171-183.

Verzera, A., Dima, G., Tripodi, G., Condurso, C., Crinó, P., and Romano, D. (2014). Aroma and sensory quality of honeydew melon fruits (Cucumis melo L. subsp. melo var. indorus H.) in relation to different rootstocks. Scientia Horticulturae, 169: 118-124.

Wang, Y.H., Behera, T.K., and Kole, C., (2011). Genetics, genomics and breeding of cucurbits. CRC Press, pp. 309-335.

$\mathrm{Xu}$, C.Q., Li, T.L., and Qi, H.Y. (2006). Effects of grafting on development, carbohydrate content, and sucrose metabolizing enzymes activities of muskmelon fruit. Acta Horticulturae Sinica, 33: 773-778.

Yarsi, G., Sari, N., Sari, N., Solmaz, I., and Aras, V. (2012). Determination of aroma compounds of grafted and ungrafted Galia C8 melo cultivar in greenhous growing. In: Sari, N., Solmaz, I., and Aras, V. (Eds.), 
Cucurbitaceae 2012. Proceedings of the Xth Eucarpia Meeting on Genetics and Breeding of Cucurbitaceae, Antalya, Turkey, 15-18 October. Ziraat Fakultesi, University of Cukurova, Turkey, pp. 415-420. Yetisir, H. and Sari, N. (2003) Effect of different rootstock on plant growth, yield and quality of watermelon. Australian Journal of Experimental Agriculture, 43: 1269-1274.

Zhao, X., Guo, Y., Huber, D.J., and Lee J. (2011). Grafting effects on postharvest ripening and quality of 1-methylcyclopropene-treated muskmelon fruit. Scientia Horticulturae, 130: 581-587.

Open Access. This is an open-access article distributed under the terms of the Creative Commons Attribution 4.0 International License (https://creativecommons.org/licenses/by/4.0/), which permits unrestricted use, distribution, and reproduction in any medium, provided the original author and source are credited, a link to the CC License is provided, and changes - if any - are indicated. (SID_1) 